\title{
A Teremtés védelme és az emberi jogok
}

\section{BÁNDI GYULA ${ }^{1}$}

Évtizedek óta küszködik a nemzetközi közösség azzal, hogy hivatalosan is az emberi jogok közé emelje a környezethez való jogot akár önmagában, akár összetevöiben - különösen ilyen lehetne a vízhez való jog. A környezet védelme pedig mindennek - az ember jogoknak is - forrása és feltétele, a kereszténységben is a kezdetektöl mélyen gyökerezik, és ugyancsak évtizedek óta része az egyházak üzeneteinek. Szükségszerü volt, hogy az emberi jogok és a környezet - a Teremtés - találkozzanak ugyanezen tanításokban. Ennek útját a kezdetektöl, valamint következményeit tekintem át a következőkben, kiemelt figyelemmel a Katolikus Egyház tanitására.

Kulcsszavak: teremtés, teremtésvédelem, ökológiai megtérés, a Katolikus Egyház társadalmi tanítása, emberi méltóság, közjó, életminőség, környezetvédelem, jelen és jövő nemzedékek védelme, fenntarthatóság, környezethez való jog, vízhez való jog

\section{Protecting Creation and Human Rights}

The international community in the past decades has been struggling for raising the right to environment officially into the body of human rights, either on its own or in constituents - such as the right to water. Although environmental protection is the basis and condition of everything - also of human rights -, deeply based in Christianity and also part of the messages of the Church for decades. It has also been inevitable that human rights and environment - the Creation - should come together in the same teaching. Next, I shall follow this road from the beginning, together with its consequences, with a special focus on the teaching of the Catholic Church.

Keywords: creation, protection of creation, ecological conversion, social teaching of the Catholic Church, human dignity, common good, quality of life, environmental protection, protection of present and future generations, sustainability, right to environment, right to water

1 Tanszékvezető egyetemi tanár, PPKE JÁK; e-mail: bandi.gyula@jak.ppke.hu 


\section{Kiindulás}

A kereszténység történetének kiindulási pontján találjuk a Teremtés leírását a Bibliában, valamint az abból eztán következő feladatokat, üzeneteket az emberiség számára. Mindezek egy keresztény tradíciós rendben öltenek testet, amelynek egyes elemeit eltérő időkben eltérően magyarázták - az ember teremtett világ feletti uralmával kapcsolatos felfogás változása, amire alább kitérek, erre jó példával szolgál. Egy keresztény szellemiségű, számos egyházi szervezetet tömörítő ökomenikus európai környezetvédelmi szervezet (European Christian Environmental Network) 2005. évi jelentésében minderről világos összegzést találunk:

„A keresztény tradíciók rendkívül gazdagok annak leírásában, hogy mi az ember szerepe és felelőssége a Teremtés kapcsán. Neveznek minket teremtményeknek, szolgáknak, pásztoroknak, prófétáknak, királyoknak és együttmüködőknek. Fel kell ismernünk az emberi uralom által okozott károkat. Tudnunk kell, hogy Isten minden embernek, akit a képére és a hasonlatosságára teremtett, olyan felelősséget és szerepet adott, hogy a teremtés papjai és az Isten munkatársai legyenek (Ter 1,28). [...] A természeti erőforrások kezelése során, amikor azokat emberi árukká és szolgáltatásokká alakítjuk, elvesszük Isten ajándékát, és elfogadjuk az ennek átalakításában megjelenő felelősségünket.”

A zsidó-keresztény hagyományban a teremtett világgal való sajátos kapcsolat alapvető kérdésként jelenik meg. ${ }^{3}$

A vallási felfogásokban általában megjelenő környezetvédelmi hagyományok szép példáját adja a Gabčíkovo-Nagymaros Project ítélethez ${ }^{4}$ füzött különvéleményében a Nemzetközi Jogi Bíróság akkori alelnöke, Christopher Weeramantry, a kortárs nemzetközi környezetjog egyik alapvető elvét vetve össze egy másik világvallás, a buddhizmus eszméivel: „Másoknak ártalmat nem okozni és ebből adódóan sic utere tuo ut alienum non laedas - központi fogalom ez a buddhizmusban. Ugyanakkor jól átültethető volt a környezetvédelmi megközelítésre. Az »alienumot« a buddhizmus ebben az összefüggésben a jövő nemzedékekre, valamint az emberen túl a természeti rend egyéb összetevőire is kiterjesztené, hiszen a kötelesség buddhista felfogásának hihetetlenül nagy a terjedelme."5 Majd számos példa felsorolását követően megállapítja: „A hagyományos bölcselet, amely ösztönzést nyújtott az ókori jogrendek számára, képes volt az ilyen problémák kezelésére.” A hangsúly sajnos a „volt” szócskán van,

2 European Christian Environmental Network: The Churches' Contribution to a Sustainable Europe (2005). Elérhető: www.ecen.org/index.php/articles/churches-contribution-sustainable-europe (A letöltés dátuma: 2020.10. 01.)

3 Pl. ennek összegzése a zsidó vallásban Josie Lacey: Environmental Ethics in Judaism (2006). Elérhető: www.ijs.org.au/environmental-ethics-in-judaism (A letöltés dátuma: 2020. 10. 01.)

4 A Nemzetközi Bíróság 1997. szeptember 25-i ítélete, Magyarország és Szlovákia jogvitája. Elérhető: www.icj-cij.org/en/case/92/judgments (A letöltés dátuma: 2020. 10. 01.) 
mert ma ez messze nem igaz, ma már hiányozni látszik az emberiségen belül az a hagyományos bölcselet, amelyre a bíró hivatkozik.

Mielőtt a téma részletes tárgyalásába fognánk, még egy részt emeljünk ki Weeremantry különvéleményéből, ezúttal a jogrend és a társadalom gyakorlati müködésének kiemelkedően fontos elemére, a hagyományokra utalva:

„A hagyományos jogrendekben létezik néhány elv, amely beleszőhető a jelenlegi környezetvédelmi jog szövetébe. Ezek különösen kapcsolódnak a fenntartható fejlődés fogalmához, amelyet azok a rendszerek elismertek. Sőt ezen jogrendek közül több is sajátosan kapcsolódik a jelen perhez, amennyiben folyamok és folyók megfékezésére vonatkoznak, és azt az aggodalmat tükrözik, hogy a természet folyamatába beavatkozó emberi tetteket mindig csak a környezet védelmének megfelelő figyelembevételével szabad végrehajtani. Általában véve a környezeti tapasztalatok vonatkozásában sok mindent lehetne átvenni az ősi civilizációktól és a hagyományos jogrendektől Ázsiában, a Közel-Keleten, Afrikában, Európában, Amerikában, a csendes-óceáni térségben, valamint Ausztráliában, valójában tehát az egész világon. Ez igen gazdag forrás, amit a modern környezetvédelmi jog eddig nagyrészt kihasználatlanul hagyott."

Márpedig jó lenne ilyesféle gyökereinkbe kapaszkodni, nem csoda, hogy a kérdéses ügyben a Nemzetközi Bíróság maga is kiemelte: „Az emberiség a történelem során, gazdasági és egyéb okok miatt, folyamatosan beavatkozott a természet rendjébe.”

A vallási vagy egyéb elvárások, hagyományok tehát az emberiség egész történelme során meghatározók, és jobbára a természettel és környezettel való harmonikus viszonyt alakítottak ki - egészen a közelmúltig. Az emberiség ugyan valóban beavatkozott a természet rendjébe, de ennek elsősorban lokális következményeit tapasztalhattuk, az összképet nem befolyásolták.

\section{A Teremtés és a Biblia}

Kiindulási pontunk tehát a Teremtés és a Biblia, ezért alapozzunk továbbra is ezekre! Azok számára, akik az alábbi rövid összegzésen túl több részletet is szeretnének megismerni, javaslom egy neves amerikai emberi jogi professzor vonatkozó cikkét, ${ }^{7}$ amelynek itt csupán az összegzéséből idézek: „A Biblia alapvető üzenete az, hogy a természetet tisztelni kell mint Isten teremtésének részét, amit az ember nem rombolhat le."

6 A Nemzetközi Bíróság 1997.szeptember 25-iítélete i. m. (4. lj.) 140.

7 Dinah Shelton: Nature in the Bible. GWU Law School Public Law Research Paper, 371. (2007). Elérhető: https://ssrn.com/abstract=1028357 (A letöltés dátuma: 2020. 10. 01.)

8 Uo. 15. 
A kezdet kétségkívül a Teremtés könyve, ${ }^{9}$ amelyet jobbára mindenki ismer, és ennek is az őstörténetről szóló része, a Teremtés napjainak leírásával. Anélkül, hogy ennek részleteit felidéznénk, figyelmet érdemel a sorrend: 1. nappal és éjjel; 2 . ég; 3. vizek és szárazföld, növények; 4. a két világító (Nap és Hold); 5. élőlények, külön a madarak; 6. vadak, háziállatok és az ember, Isten képmására. „1,28. Isten megáldotta őket, Isten szólt hozzájuk: »Legyetek termékenyek, szaporodjatok, töltsétek be a földet, és vonjátok uralmatok alá. Uralkodjatok a tenger halai, az ég madarai és minden állat fölött, amely a földön mozog «.” Több kérdés érdemel külön figyelmet: a teremtés sorrendje és ebben az ember helye, illetve ennek révén az ember sajátos kettőssége: rá van utalva a Teremtés megelőző és párhuzamos elemeire, de egyben uralmat is kapott felettük. Ez utóbbi kérdés vált sokak számára botránykővé, amíg meg nem értjük ennek lényegét. Az „uralom” szó félreértelmezése ugyanis egyesek számára annak üzenete, hogy a természetet le kell igázni, ki kell használni, nem pedig tisztelni, megóvni.

Visszatérve a Teremtéshez, folytatva immár a Paradicsommal, a fenti félreértelmezésre is reagálva ki kell emelnünk egy fontos bibliai gondolatot: „2,15. Az Úristen vette az embert és Éden kertjébe helyezte, hogy művelje és őrizze." Ez már egy kissé pontosabb utalás, mit is értünk a fenti uralom fogalma alatt. Sem a művelés, sem az őrzés nem azonosítható a kizsákmányolással, leigázással, éppen ellenkezőleg, az a felelősség érződik benne, amelyre a pápai üzenetek hívják fel a figyelmet az utóbbi évtizedekben.

Az tehát már nem lehet kétséges, hogy a Teremtés könyvében szereplő utalás az ember uralmára a természet felett $($ Ter 1,28$)$ felelős örzést jelent, gondoskodást a rábízottakról. Ezt II. János Pál már 1979-ben is világossá tette, ítéletet mondva egyben az ember pazarló gazdálkodásáról: ${ }^{10} „ 15$. [...] A Teremtő azonban úgy akarta, hogy az ember közösségben éljen a természettel mint értelmes és nemes ura, mint őrzője, s nem mint garázda birtokosa, aki mindent kiárusít, s mindenre tekintet nélkül pusztítja a természetet." A Teremtés könyvében és máshol az Ószövetségben az sem kétséges, hogy a kérdéses felelős őrző az egész emberiség, minden generációjával és nemzetségével egyetemben. Az Úr így szólt Ábrahámhoz: „Általad nyer áldást a föld minden nemzetsége" (Ter 12,3). Ugyancsak ószövetségi gondolattal folytatva a vonatkozó üzeneteket: „Így hát válaszd az életet, hogy te is, utódaid is életben maradjatok" (MTörv 30,19). Ezek az üzenetek és jó néhány más utalás világossá teszik, hogy az ember teremtése - valójában az emberiség teremtése - az emberi generációk folyamatosságát jelenti.

A Gaudium et spes ${ }^{11}$ efelől már másfél évtizeddel korábban sem hagyott kétséget: „69. Isten a földet minden kincsével együtt minden ember és minden nép használatá-

9 Jelen tanulmányban a Szentírást a következő forrásra alapozva idézem: https://szentiras.hu/szit (A letöltés dátuma: 2020. 10. 01.)

10 II. János Pál pápa: Redemptor hominis (Az emberek Megváltója) (1979). Elérhető: https://regi.katolikus.hu/konyvtar.php?h=206 (A letöltés dátuma: 2020. 10. 01.)

11 II. Vatikáni Zsinat: Gaudium et spes, a II. Vatikáni Zsinat lelkipásztori konstitúciója az Egyházról a mai világban (1965). Elérhető: https://regi.katolikus.hu/konyvtar.php?h=16 (A letöltés dátuma: 2020. 10. 01.) 
ra rendelte. Ezért a teremtett javaknak méltányos arányban kell eljutniok mindenkihez a szeretettől kísért igazságosság vezetése mellett. [...] Az embernek tehát, amikor a teremtett javakat használja, úgy kell tekintenie jogosan birtokolt vagyonát, hogy az nemcsak a sajátja, hanem egyúttal közös is, abban az értelemben, hogy ne csak önmagának, hanem másoknak is hasznára lehessen."

II. János Pál, amikor centenáriumi enciklikájában ${ }^{12}$ a Rerum novarum ${ }^{13}$ újraolvasását is javasolta, még egyértelmübben fogalmazott: „31. [...] Isten - anélkül, hogy bárkit is kizárt vagy előnyben részesített volna - az egész emberi nemnek adta a földet, hogy valamennyi tagját éltesse. Ebben rejlik a földi javak egyetemes rendeltetésének gyökere."

Visszakanyarodva a Teremtés könyvéhez, Noé története lehet a következö, hiszen ebből lesz érthető az is, hogy - ellentétben a mai ember elbizakodott felsőbbségével - nincs felesleges vagy szükségtelen teremtmény: „7,1. Az Úr így szólt Noéhoz: "Szállj be egész családoddal a bárkába, mert csak téged találtalak igaznak színem előtt az egész nemzedékben. 2 . Minden tiszta állatból vigyél hetet-hetet, hímet és nőstényt, a tisztátalanokból pedig kettőt, hímet és nőstényt. 3. (A madarakból is hetet-hetet, hímet és nőstényt), hogy ivadékuk az egész földön életben maradjon«"”

Sőt a Biblia általában is számos további fontos tanácsot ad a Teremtés könyve müvelés és ốrzés üzenete kapcsán. Egy példát kiemelve a Második Törvénykönyvből a természet tiszteletére és észszerű védelmére: „22,6. Ha útközben meglátsz a fán vagy a földön egy madárfészket, amelyben fiókák vagy tojások vannak, $\mathrm{s}$ az anyamadár rajta ül a fiókákon vagy a tojásokon, ne fogd meg az anyamadarat a fiókákkal együtt. 7. Ha a fiókákat ki is szeded, az anyamadarat hagyd elrepülni, hogy jól menjen a sorod és sokáig élj." Egy másikat pedig általában a gazdálkodásra nézve a Kivonulás könyvéből: „23,10. Hat éven át vesd be földedet és arasd le termését, 11. a hetedik évben azonban hagyd ugaron és ne nyúlj a terméshez, hogy néped szegényei éljenek belőle. Amit ezek otthagynak, legyen a föld vadjaié. Ugyanígy tégy szőlőddel és olajfáiddal. 12. Hat napon át végezd munkádat, a hetedik napon szünetelj, hogy ökröd és szamarad is pihenjen, s hogy szolgálód fia és az idegen is felüdüljön."

Dinah Shelton idézett munkája hívta fel a figyelmemet egy olyan bibliai történetre, amely arra mutat rá, hogy a teremtett világ és élőlényei milyen közel is állnak a Teremtőhöz, alkalmanként közelebb, mint az ember. Ez Bálám (Bileám) szamarának története a Számok könyvéből: „31. Az Úr most megnyitotta Bileám szemét, így meglátta az Úr angyalát, amint kivont kardot tartva kezében ott állt az úton. Erre meghajolt és arcra borult. 32. Az Úr angyala azonban így szólt hozzá: „Miért verted meg háromszor is a szamarat? Lásd, én álltam utadat, mert sietésed ellenemre van.

12 II. János Pál pápa: Centesimus annus, enciklika a Rerum novarum enciklika kibocsátásának századik évfordulója alkalmából (1991). Elérhető: https://regi.katolikus.hu/konyvtar.php?h=86 (A letöltés dátuma: 2020. 10. 01.)

13 XIII. Leó pápa: Rerum novarum, enciklika a munkáskérdésről (az első pápai szociális körlevél) (1891). 
33. A szamár észrevett, s már háromszor kitért előlem. Ha nem tért volna ki, akkor bizony már megöltelek volna, de őt életben hagytam volna.”

Utolsó példánkban - Jób könyve - az Úr az elbizakodott embert próbálja helyre tenni számos egyéb mellett a következő szavakkal: „38,4. Mikor a földet alkottam, hol voltál? Mondd csak meg, ha egyszer oly nagy a bölcsességed! [...] 33. Tudsz-e valamit a mennybolt törvényéről, uralmát a földön te határozod meg? 34. És ha a felhőkig fölemeled hangod, szót fogadnak-e neked az áradó vizek? [...] 39,26. Bölcsességed szerint szállt talán a sólyom, s terjeszti szárnyait dél felé repülve? 27. A te parancsodra száll a sas fölfelé és építi a fészkét a magasságokba?"

A Biblia, a kereszténység alapműve tehát a Teremtésben közvetlen alkotó szerepet nem szán az embernek - emberiségnek -, később azonban elvárja a teremtett világról való gondoskodást, olyan követelményekkel, amelyek a teremtés egészének megőrzésére irányulnak, olyan magatartást várva el, amely nem egyesek, hanem az emberiség egészének javára szolgál, az emberiség fennmaradásának feltétele.

\section{A Katolikus Egyház üzenete a környezetvédelemröl}

Fentebb már említettük a közel 130 éves Rerum novarumot, amely valójában elöször szembesíti átfogó módon az egyházat a társadalmi problémákkal, viszi közelebb a mindennapi élethez. Olyan kérdésekkel foglalkozik, mint az emberi természet és jogai, a közjó és a javak rendeltetése, a szolidaritás és a szeretet, a család, az emberi munka, az erkölcs és a gazdaság, a politikai és társadalmi közösségek - minden szinten - megjelenő szerepe és felelőssége, illetve a nemzetközi közösség hasonlóan növekvő súlyát, sőt a béke lényegi kérdéseit is érinti.

Száz évvel később az évfordulós Centesimus annusban II. János Pál emlékeztetett arra, hogy az eredeti enciklika alapvető értékeinek egyike, hogy időnként megújítható: „3. Szeretném most javasolni XIII. Leó enciklikájának »újraolvasását« [...] Biztatok arra is, hogy figyelmesen vegyük szemügyre az »új dolgokat«." Ez bátorít fel engem is arra, hogy felfedezni véljem a környezetvédelem mai kérdéseinek alapjait is a Rerum novarumban, hiszen az enciklika kiemelkedö jelentösége az, hogy mozgásba kívánja hozni az egyházat társadalmi kérdések, különösen a szociális kérdések, a tulajdon, a gazdaság és a munka tekintetében. Az új kérdések, új dolgok maguk is megújulnak, hiszen ezzel az enciklikával valami elkezdődött, és már abban is megjelent a természet, a közjó és a mindezeket kormányozni hivatott józan ész, az ember felelős magatartása: „5. Ami az emberben messze kiemelkedik, ami az embert emberré teszi és az állatoktól lényege szerint megkülönbözteti, az az ész, vagyis az értelem. $\mathrm{S}$ mivel kizárólag az ember ésszel bíró lelkes lény, szükségszerü, hogy neki a javak nemcsak használatára vannak rendelve, mint az összes többi lelkes lénynek, hanem tartós és örökös jogú birtokul, és nem csupán olyan javak, amelyek használat közben felemésztődnek, hanem olyanok is, amelyek használat mellett is megmaradnak. [...] 21. [...] A természetes javak, mint az isteni kegyelem ajándékai is, ugyanígy közösen és egyformán állanak az egész emberi nem rendelkezésére." Nyilván a megfogalmazás 
némileg eltér az utóbbi évtizedek egyházi megnyilatkozásaitól, de a lényeg érzékelhető: a természetes javakat nem lehet kisajátítani, azok az ember egyetemes felelösségére vannak bízva.

Az eredeti enciklika után 40 évvel a Quadragesimo anno ${ }^{14}$ máris új elemeket kapcsolt az eredeti gondolatokhoz. Ezek legismertebbje a kisegités elve (principium subsidiaritatis), mégpedig a közjó érdekében. Ez lesz az az alapelv, amely éppen a környezetvédelmi szabályozásban jelent meg először az európai integrációban, mégpedig az Egységes Európai Okmány környezetvédelmi címében 1987-ben..$^{15}$ Az enciklika 104. pontja szerint pedig figyelemmel kell lenni arra, hogy mi jó az egész emberiségnek, tehát a közjó gondolata világlik ki belőle. 1931 után azonban egyre inkább más történelmi kérdések foglalkoztatták az egyházat is, a közjó kérdésének további kifejtése váratott magára.

A háború lezárását követően kezdett visszatérni az élet a rendes kerékvágásba, és ezzel együtt, már a 60-as évektől egyre jobban érzékelhető volt az ember által előidézett súlyosbodó környezeti terhelés. A 60-as évek elején megjelent pápai enciklika ugyan alapvetően a békére gondolt, és egyben első nagy lépés az emberi jogok megjelenése kapcsán is (Pacem in terris $\left.{ }^{16}\right)$. A környezeti vonatkozások itt még csupán kezdetiek: „2. Mert a tudományok haladásából és a technikai találmányokból világosan tudjuk, hogy csodálatos rend uralkodik az élők világában és a természet erőiben. [...] 55. Továbbá a közjóban benne kell lennie mindannak, ami az egyes nemzeteket egyenként megilleti; de ezek legkevésbé sem határozzák meg a közjót minden részében."

A környezetvédelmi alapozás további erősítésére sem kellett már sokat várni: két évvel később egy következő pápa - VI. Pál - erre vonatkozóan megteremtette az egyházi hozzáállás alapjait - ez a Gaudium et spes: „36. [...] Épp a teremtés tényéből következik ugyanis, hogy minden dolognak megvan a maga állaga, igazsága és jósága, megvannak a saját törvényei, és megvan a saját rendje: ezeket az embernek tisztelnie kell, ismervén a tudományok és művészetek sajátos módszereit. [...] A teremtmény ugyanis a Teremtő nélkül elenyészik." Majd a fentebb, a Biblia értelmezése kapcsán hivatkozott 69. pont második részét emeljük ki ismételten: „Az embernek tehát, amikor a teremtett javakat használja, úgy kell tekintenie jogosan birtokolt vagyonát, hogy az nemcsak a sajátja, hanem egyúttal közös is, abban az értelemben, hogy ne csak önmagának, hanem másoknak is hasznára lehessen."

Az ember felelőssége a teremtett világért - ez pedig valójában azonosítható azzal is, amit ma környezetvédelmi megfontolásoknak, sőt már fenntartható fejlődésnek

14 XI. Pius pápa: Quadragesimo anno, enciklika a társadalmi rend megújításáról (1931). Elérhető: http://tarsadalomformalas.kife.hu/xi-pius-papa-quadragesimo-anno (A letöltés dátuma: 2020. 10. 01.)

15 Az Egységes Európai Okmány 130r. cikk 4. pontja szerint: „A Közösség olyan mértékben folytat a környezetre vonatkozó tevékenységet, amelyben az 1 . bekezdésben hivatkozott célok jobban valósíthatók meg Közösségi szinten, mint az egyes Tagállamok szintjén."

16 XXIII. János pápa: Pacem in terris, enciklika az igazságon, igazságosságon, szereteten és szabadságon felépítendő békéről a nemzetek között (1963). Elérhető: www.vatican.va/content/john-xxiii/hu/ encyclicals/documents/hf_j-xxiii_enc_11041963_pacem.html (A letöltés dátuma: 2020. 10. 01.) 
mondunk - egyre markánsabban jelent meg. A Populorum progressióban ${ }^{17}$ is megfigyelhető a Rerum novarumban megjelent gondolat továbbvitele, mégpedig általában a gazdaság, a gazdasági fejlődés korlátainak, felelősségének kiemelése révén. Ebben az enciklikában olyan gondolatok jelennek meg, amelyekkel párhuzamot vonhatunk az akkortájt még alakulóban lévő, de 1972-ben megvalósuló ENSZ stockholmi környezetvédelmi világértekezletén vagy az EGK párizsi csúcskonferenciáján már világosan megfogalmazottakkal. Gondolhatunk egyebek között a fejlődés valós jelentésére: „14. Az a fejlődés, amiről itt szó lesz, nem szorítkozik a puszta gazdasági növekedésre. Hiszen a fejlődésnek, hogy valóságosnak legyen mondható, minden oldalúnak kell lennie, olyannak, amely minden ember és a teljes ember növekedését biztosítja." ${ }^{18}$ Az enciklika szerint: „76. A fejlődés nem csupán a jólét, hanem a szellemi és erkölcsi fejlődés is, amely az egész emberi faj előnyére válik." Természetesen helyet kap a szolidaritás, a béke, tehát a „jólét” helyett az általam szívesebben alkalmazott „jól lét” (well-being).

Nem sokkal a fenti enciklikát követően az ENSZ keretei között - a párizsi csúcscsal párhuzamosan -rendezték meg a stockholmi konferenciát az emberi környezetröl, amelyik elfogadta a Stockholmi nyilatkozatot. Ennek 4. pontja elismeri azt a különleges felelősséget, amelyet az embernek a természeti környezet megóvása érdekében viselnie kell. És csupán a párhuzamosság kedvéért mindenképpen említést érdemel a hazai 1975. évi II. törvény az emberi környezet védelméről, amelyre az előbbiek közvetlen hatást gyakoroltak.

A megkezdett utat - kis szünetet követően - II. János Pál pápa folytatta a Redemptor hominis enciklikában, méghozzá az elődökhöz képest sokkal világosabban és közvetlenebbül utalva a modern kor veszélyeire: „15. Mitől fél a modern ember?” - teszi fel a kérdést, amelyet a természet és ember viszonya kapcsán így válaszol meg: „Egyre inkább be kell látnunk, hogy a föld javainak fölhasználásában tisztességgel és értelmesen kell eljárnunk. [...] Így a természetes környezetben az ember már nem lát egyebet, mint a közvetlen fölhasználás és a fogyasztás számára hasznos dolgot. A Teremtő azonban úgy akarta, hogy az ember közösségben éljen a természettel mint értelmes és nemes ura, mint őrzője, s nem mint garázda birtokosa, aki mindent kiárusít, s mindenre tekintet nélkül pusztítja a természetet." A kulcs itt ismét az emberi méltóság, amely szorosan kapcsolódik a környezet megfelelő értékének, a fejlődés tényleges értelmének felismeréséhez. Az ember felelőssége pedig hangsúlyos, és ezzel visszauta-

17 VI. Pál pápa: Populorum progressio, enciklika az emberek fejlődéséről (1967). Elérhető: https://regi. katolikus.hu/konyvtar.php?h=462 (A letöltés dátuma: 2020. 10. 01.)

18 A tagállamok állam- és kormányfőinek 1972 októberében Párizsban megrendezett csúcskonferenciája hasonlóan fogalmaz: „A gazdasági növekedésnek, amely önmagában nem végcél, elsődlegesen az életfeltételekben mutatkozó különbségek enyhítéséhez kell hozzájárulnia. Ennek az összes társadalmi partner részvételével kell végbemennie, az életminőség és az életszínvonal javítását kell eredményeznie. Az európai eszméhez illően különös figyelmet kell szentelni a kézzel nem fogható értékeknek és a környezet védelmének, oly módon, hogy a haladás valóban az emberiség szolgálatába állítható legyen." Elérhető: www.cvce.eu/content/publication/1999/1/1/b1dd3d57-5f314796-85c3-cfd2210d6901/publishable_en.pdf (A letöltés dátuma: 2020. 10. 01.) 
lok arra a látszólagos ellentmondásra, amely a bibliai uralom és őrzés üzenetei között van, egyes túlzó értelmezések szerint.

Ugyancsak határozott választ ad a fejlődés valós értékeire és tartalmára a Sollicitudo rei socialis enciklika: ${ }^{19}$ „34. A fejlődés erkölcsi jellege nem tekinthet el a teremtmények tiszteletétöl sem, amelyek a látható természetet alkotják, és amelyet a görögök a bennük tapasztalt rend miatt kozmosznak neveztek. [...] A Teremtőtől kapott hatalom, amellyel az embert felruházta, nem abszolút, nem szabad vele »élni vagy visszaélni«, vagy tetszés szerint felhasználni. A használati mód, amelyre a Teremtő már kezdetben utasította az embert, jelképesen benne van a tiltásban: »annak a fának gyümölcséből ne egyél« (vö. Ter 2,16-17).”

II. János Pál 1990-ben elindította azt a sort, amely a béke világnapja alkalmából kiadott üzenetekben egyre mélyebb környezeti tartalmat is közvetít:: „7. A legmélyebb és legkomolyabb jele a morális elem alapvető jelenlétének az ökológiai válságban az élet tiszteletének hiánya, ami a környezetszennyezés számos esetében megnyilvánul. [...] Az élet, és mindenekelőtt az emberi méltóság tisztelete az alapvető vezérlő elve mindenfajta egészséges gazdasági, ipari vagy tudományos fejlődésnek. [...] 13. A modern társadalom nem lesz képes megoldást találni az ökológiai válságra, hacsak komolyan át nem gondolja egész életformáját."

Fentebb már említettük a Centesimus annust, amelynek központi kérdése a közjó, és ennek tagadhatatlan részei a környezeti értékek: „37. A fogyasztás kérdése mellett az ehhez szorosan kapcsolódó ökológiai probléma is komoly nyugtalansággal tölt el. [...] Az ember helytelenül Isten helyébe lép, és így végeredményben elősegíti az általa inkább elnyomott, semmint kormányzott természet lázadását, ahelyett, hogy a teremtés művében Istennel müködne együtt. [...]. E téren is tudatában kell lennie az emberi nemnek, hogy felelősséggel és következetességgel tartozik a jövő nemzedékekkel szemben." A piac pedig nem alkalmas ennek kezelésére. Időközben az ENSZ is készült a környezet és a fejlődés szempontjainak összerendezésére, amelynek az 1992. évi „Környezet és fejlődés” konferencia lett a kicsengése és a fenntartható fejlődés a következtetése. $^{21}$

Noha a következő enciklika - Evangelium vitae ${ }^{22}$ - kevesebbet foglalkozott a környezettel, lehetetlen nem szólni róla: „42. Mivel az ember arra hivatott, hogy művelje és őrizze a világ kertjét, különleges felelösséggel tartozik az élő környezetért, azaz a teremtésért."

19 II. János Pál pápa: Sollicitudo rei socialis, enciklika a Populorum progressio enciklika huszadik évfordulójára (1987). Elérhető: https://regi.katolikus.hu/konyvtar.php?h=93 (A letöltés dátuma: 2020. 10. 01.)

20 II. János Pál pápa: Békesség a teremtö Istennel. Békesség az egész teremtett világgal (1990). Elérhető: www.teremtesvedelem.hu/content/cikk/az-okologiai-valsag-kozos-felelossegunk (A letöltés dátuma: 2020. 10. 01.)

21 ENSZ Környezet és Fejlődés Konferencia: Riói Nyilatkozat a Környezetről és a Fejlődésről (1992). Magyarul megjelent: Fizikai Szemle, 43. (1993), 4. 123-124.

22 II. János Pál pápa: Evangelium vitae, enciklika az emberi élet sérthetetlenségéről (1995). Elérhető: https://regi.katolikus.hu/konyvtar.php?h=78 (A letöltés dátuma: 2020. 10. 01.) 
A Velencei nyilatkozat ${ }^{23}$ - az ökumené jegyében - az egész addigi II. János Pálgondolatsor összegzése: „A teremtés tisztelete az emberi élet és méltóság tiszteletéből fakad. [...] A gond nem pusztán gazdasági vagy technológiai, elsősorban erkölcsi és lelki. [...] Nincs végtelen hatalmunk a teremtés felett, csupán sáfárai vagyunk közös örökségünknek." Ez az erkölcsi megújulásra szólító felhívás jelent meg egy későbbi békevilágnapi üzenetben is: „6. Mivel a béke ajándéka szorosan kötődik a népek fejlődéséhez, nélkülözhetetlen számításba venni azt az erkölcsi következményt, amely a föld javainak használatából ered."24

$\mathrm{Az}$ eddigiekben saját szempontjaim és gondolatmenetem szerint mutattam be a bibliai és a vatikáni forrásokat, alapokat. Nyilván van ennél sokkal hitelesebb és szebben felépített forrás, és ez Az Egyház társadalmi tanításának kompendiu$m a{ }^{25}$ annak is 10 . fejezete, amelyik a környezetvédelemre vonatkozik. A kompendium az alapoktól kezdve tekinti át a kereszténység hozzáállását, ezért mindebben megfelelő egyensúlyra törekedve emeli ki: „463. A környezet helyes felfogása egyrészt nem teheti a természetet a manipuláció és a felhasználás puszta tárgyává, másrészt nem is abszolutizálhatja azt, és méltóságát nem állíthatja az emberi személy méltósága fölé.” Illetve később: „465. Mint a Tanítóhivatal hangsúlyozza, az ember felelős azért, hogy a környezetet sértetlenül és egészségesen őrizze meg mindenki számára." „466. A környezetvédelem az egész emberiséghez szóló kihívás. Közös és átfogó kötelességről van szó, közös tulajdonunk megóvásáról, amely mindenkit szolgál." Számos más fontos kérdésre világít rá emellett, kiemelve nem egy számunkra fontos területtel kapcsolatos üzenetet: „A biológiai sokféleséggel felelősségtudattal kell foglalkozni, és megfelelő módon oltalmazni kell, mert ez az egész emberiség számára rendkívüli gazdagságot jelent." Úgyszintén hangsúlyozza a jövő nemzedékek iránti felelősséget: „467. A környezetért való felelősség, amely az emberi nem közös értékének bizonyul, nem pusztán a jelennel, hanem a jövővel kapcsolatos követelésekre is kiterjed.”

Mielőtt folytatnánk a pápai üzenetek sorát, mindenképpen időznünk kell a Magyar Katolikus Püspöki Konferencia körlevelénél ${ }^{26}$ is - időrendben is így következik -, amely a hazai egyház számára hordoz fontos üzenetet, átfogó és érdemi öszszegzést adva az eddigiekről.

23 II. János Pál pápa - I. Bartholomaiosz ökumenikus pátriárka: Velencei Nyilatkozat, közös nyilatkozat a környezeti etikáról (2002). Elérhető: www.teremtesvedelem.hu/content/cikk/velencei-nyilatkozat (A letöltés dátuma: 2020. 10. 01.)

24 II. János Pál pápa: Ne engedd, hogy legyözzön a rossz, hanem te gyözd le a rosszat jóval. A pápa üzenete a béke világnapjára (2005). Elérhető: https://regi.katolikus.hu/konyvtar.php?h=24 (A letöltés dátuma: 2020. 10. 01.)

25 Az Igazságosság és Béke Pápai Tanácsa: Az Egyház társadalmi tanításának kompendiuma. Őszentsége II. János Pál pápának a Társadalmi Tanítás Tanítómesterének, az Igazságosság és a Béke Evangéliuma Tanúságtevőjének (2004). Elérhető: www.vatican.va/roman_curia/pontifical_councils/ justpeace/documents/rc_pc_justpeace_doc_20060526_compendio-dott-soc_hu.html (A letöltés dátuma: 2020. 10. 01.)

26 Magyar Katolikus Püspöki Konferencia: Felelösségünk a teremtett világért (2008). Elérhető: www. teremtesvedelem.hu/content/korlevel/felelossegunk-teremtett-vilagert (A letöltés dátuma:

2020. 10. 01.) 
„22. [...] Mivel a gazdasági, pénzügyi logika diktálja a politikai döntéseket és gyakran társadalmi értékítéleteinket is, ezért hajlamosak vagyunk eltekinteni a gazdasági növekedés azon közvetett költségeitől, amelyek más területeken, a természeti környezetben vagy a szociális szektorban hosszú távon jelentkeznek. [...] 169. [...] A környezet megóvása több, mint a jelen és a jövő generációk méltó életkörülményeinek biztosítása, hiszen az ember Istennel, az emberekkel és a teremtett világgal való kapcsolata egységet alkot. A természeti környezet megóvása nem más, mint a közjó, vagyis az emberi méltóság védelme és előmozdítása."

XVI. Benedek pápa követi az immár több évtizedes utat, amikor a Populorum progressióról is megemlékezik Caritas in veritate enciklikájában. ${ }^{27}$

„7. [...] A közjó az egyénekből, családokból, köztes csoportokból formált és társadalmi közösséggé egyesülő »mindannyiunk« java. [...] 23. [...] Ki kell azonban mondanunk, hogy a csupán gazdasági és technológiai szempontú fejlődés nem elégséges. [...] 48. A fejlődés témája ma szoros kapcsolatban van azokkal a kötelességekkel, amelyek az embernek a természethez füződő kapcsolatából fakadnak. [...] 50. [...] Tudatában kell lennünk azonban annak a nagyon komoly kötelezettségünknek, hogy a következö generációknak Földünket olyan állapotban kell átadnunk, hogy ők is méltó módon élhessenek, és képesek legyenek tovább müvelni azt."

Ami talán a legfontosabb figyelmeztetés a fentieknek mintegy összegzéseként: „51. Az a viselkedési minta, amely alapján az ember a környezettel bánik, befolyással van arra a viselkedési módra is, ahogyan önmagával bánik, és viszont. [...] a meghatározó probléma a társadalom általános erkölcsi magatartása." A környezetvédelem következésképpen nem választható el az emberiség más problémáitól, ezek csak együtt kezelhetők.

Folytatódnak a békevilágnapi üzenetek is, a tíz évvel ezelőttinek a címe is beszédes: Ha békére törekszel, védd a teremtett világot, ${ }^{28}$ üzenete pedig világos:

„1. A teremtett világ tiszteletben tartásának nagy jelentősége van azért is, mert »a teremtés Isten minden művének kezdete és alapja «, megóvása napjainkban lényegbevágó az emberiség békés együttélése szempontjából. [...] 5. [...] Bölcs dolog tehát alaposan és nagy távlatban felülvizsgálni a fejlődési modellt, átgondolni a gazdaság és a gazdasági célok értelmét, hogy kijavítsuk müködési zavarait és torzulásait. [...] 7. [...] a teremtett világ öröksége az egész emberiséget megilleti. [...] [A]rra van szükség, hogy jogi és gazdasági szempontból is jól meghatározott

27 XVI. Benedek pápa: Caritas in veritate, enciklika az ember teljes értékű fejlődéséről a szeretetben és az igazságban (2009). Elérhető: https://regi.katolikus.hu/konyvtar.php?h=397 (A letöltés dátuma: 2020. 10. 01.)

28 XVI. Benedek pápa: Ha békére törekszel, védd a teremtett világot. A pápa üzenete a béke világnapjára (2010). Elérhető: https://regi.katolikus.hu/konyvtar.php?h=229 (A letöltés dátuma: 2020. 10. 01.) 
szabályok szerint cselekedjünk, ugyanakkor kellő szolidaritással kell viseltetnünk a Föld legszegényebb területein élők és a jövő nemzedékek iránt."

A megoldás sem ismeretlen: „11. Egyre nyilvánvalóbbá válik, hogy a környezet pusztulásának problémája arra hív minket, hogy felülvizsgáljuk életstílusunkat, valamint a fogyasztás és a termelés elterjedt modelljeit, amelyek gyakran társadalmi, környezeti, sőt gazdasági szempontból is tarthatatlanok. [...] Mindannyian felelősek vagyunk a teremtett világ védelméért és megőrzéséért."

Ferenc pápa Laudato si' ökológiai enciklikája ${ }^{29}$ ebben az évben ötéves. Önmagában az a tény is kiemelkedővé teszi a vatikáni dokumentumok között, hogy ez az első olyan terjedelmes enciklika, amelyet a maga egészében az ökológiának, a fenntarthatóságnak szentelt a pápa. Az enciklika Szent Ferenc fohászából kölcsönzi címét: Laudato si, mi’ Signore („Áldott légy, Uram!”). Ferenc pápa természetesen elődei gondolataira alapoz, az ott megfogalmazottakat viszi tovább, némileg reflektálva egyben az ugyanazon évben elfogadott fenntartható fejlődési célokat (SDG) összegző ENSZdokumentumra ${ }^{30}$ is. Az SDG hazai fordításának bevezetőjében olvashatunk a két üzenet közös pontjairól: „Ezt a munkát, ezt a »rendszerszintű változást« sürgeti egyre jobban az utóbbi évtizedek keresztény társadalmi tanítása is, legutóbb Ferenc pápa »Laudato si'« kezdetú enciklikájában."

Az enciklika legfontosabb kérdésfelvetése: „160. Milyen világot szeretnénk hagyni azokra, akik utánunk jönnek, a gyermekekre, akik most nőnek fel?” A válaszhoz Ferenc pápa újraolvassa a Biblia elbeszéléseit, majd a zsidó-keresztény hagyomány alapján nyújt összetett áttekintést, és kiváltképpen azt fejtegeti, hogy az embernek „szerfölött nagy felelössége” van a teremtett világgal szemben, amely jelenti a minden teremtmény közötti bensőséges kapcsolatot; valamint kifejti azt a tényt, hogy „a környezet közjó, az egész emberiség öröksége és mindenki felelőssége" (95.). Az enciklika javaslatának középpontjában egy átfogó ökológia áll mint az igazságosság új paradigmája: „nem tekinthetjük a természetet olyan valaminek, amely tőlünk külön van választva vagy pusztán életünk kerete, [...] nem áll fenn két, egymástól független, egy környezeti és egy társadalmi válság, hanem egyetlen és összetett társadalmi-környezeti válságról van szó" (139.). A pápa ökológiai megtérésre hív fel, ahol a kiindulópont „egy másfajta életstílusra való törekvés" (203-208.).

Egy figyelemre méltó párhuzam bontakozik ki e tekintetben az Alkotmánybíróság gyakorlatában, amely mindezekre vonatkoztatva a jelen és a jövő nemzedékekkel kapcsolatos felelősség, illetve a Biblia fogalmazásából kiolvasható felelős őrzés gon-

29 Ferenc pápa: Laudato si' kezdetü enciklikája közös otthonunk gondozásáról. Budapest, Szent István Társulat, 2015. Elérhető: https://regi.katolikus.hu/konyvtar/ferenc_papa_laudato_si_enciklika.pdf (A letöltés dátuma: 2020. 10. 01.)

30 ENSZ: Világunk átalakitása: a fenntartható fejlödés 2030-ig megvalósitandó programja. Elérhető: https://jak.ppke.hu/kiadvanyaink/1-vilagunk-atalakitasa (A letöltés dátuma: 2020. 10. 01.) 
dolatát teljesíti ki, méghozzá legjobban a legutóbbi, az erdőtörvényre vonatkozó határozatában. ${ }^{31}$

„[21] 1. Az Alaptörvény P) cikk (1) bekezdése értelmében »[a] természeti erőforrások, különösen a termőföld, az erdők és a vízkészlet, a biológiai sokféleség, különösen a honos növény- és állatfajok, valamint a kulturális értékek a nemzet közös örökségét képezik, amelynek védelme, fenntartása és a jövő nemzedékek számára való megőrzése az állam és mindenki kötelessége.« [...]

[22] Az Alaptörvény P) cikk (1) bekezdése a public trust környezeti és természeti értékekre vonatkozó koncepciójának alkotmányjogi megfogalmazásán alapul, melynek lényege, hogy az állam a jövő nemzedékek mint kedvezményezettek számára egyfajta bizalmi vagyonkezelőként kezeli a rá bízott természeti és kulturális kincseket, és a jelen generációk számára csak addig a mértékig teszi lehetővé ezen kincsek használatát és hasznosítását, ameddig az a természeti és kulturális értékeket mint önmagukért is védelemben részesítendő vagyontárgyak hosszú távú fennmaradását nem veszélyezteti. Az államnak ezen kincsek kezelése és az arra vonatkozó szabályozás megalkotása során egyaránt tekintetbe kell vennie a jelen és a jövő generációk érdekeit. A természeti és kulturális erőforrások jövő nemzedékek számára történő megőrzésének magyar Alaptörvényben található szabálya ily módon az újonnan kialakult és megszilárdult univerzális szokásjog részének is tekinthető, és kifejezi az alkotmányozó elköteleződését a környezeti, természeti és kulturális értékek fontossága és megőrzése iránt."

Az enciklika ötödik évfordulója kapcsán beszélt ismét Ferenc pápa 2020. január 1-jei békevilágnapi üzenetében ${ }^{32}$ az ökológiai megtérés szükségességéről: „A természeti erőforrások, az élet számos formája és a föld maga ránk lett bízva, hogy mủveljük és őrizzük, a jövő nemzedékek számára is, mindenki felelős és aktív részvételével. [...] Az ökológiai megtérést [...] integrált módon kell érteni."

A pápai enciklikák tehát a 60 -as évektől fordítanak egyre nagyobb figyelmet a környezetvédelemre, ami számos dokumentumrészlet, békevilágnapi üzenet és más kisebb megnyilatkozásokat követően 2015-re teljesedett ki egy önálló ökológiai tartalmú enciklikában. Magától értetődően minden megnyilatkozás hasonló - bár egyre világosabb és élesebb - tartalmú, mert lényegük az ember/emberiség felelőssége, a társörökös és őrző szerep, az élet minden formájának tisztelete, a közjó azonosítása mindenki javával egyesek előnyös helyzethez jutása helyett, beleértve a környezetet is a teremtett világ részeként, az emberi méltóságról sem feledkezve meg, amely a teremtett világ nélkül nem lehet teljes értékủ. Az is egyre látványosabb, hogy a jelenlegi gazdasági érdekek és a hozzájuk kapcsolódó érdekviszonyok tévútra vezetik

31 14/2020. (VII. 6.) AB határozat.

32 Ferenc pápa: A béke mint a remény útja. Elérhető: www.katolikus.hu/cikk/ferenc-papa-uzenete-a -beke-53-vilagnapjara-a-beke-mint-a-remeny-utjaparbeszed-megbekeles-es-okologiai-megteres (A letöltés dátuma: 2020. 10. 01.) 
az emberiséget, az egész - mondjuk ki: a fogyasztóinak mondott társadalom a központi kérdés - jelen rendszernek meg kell változnia, mert társadalmi és környezeti válságban vagyunk, és válságunk alapvetően etikai válság, az értékek hamissága, az életstílus deformáltsága húzódik meg mögötte. A felelősség ugyan mindenkié, közös, de a gazdag országok, a fejlett világ felelőssége mégis nagyobb, a szolidaritás alapgondolatát is átfogva. A teremtett világ megóvása távolról sem csak az ember miatt követelmény - noha nyilván az ember ennek középpontja -, hanem ebben az embertől is függetlenül a teremtés tisztelete jelenik meg, ami persze közvetlenül visszahat ránk. Az életstílus felülvizsgálata és megváltoztatása pedig gyökeres kell legyen, ezt érthetjük az ökológiai megtérés felhívása alatt.

\section{A Katolikus Egyház és az emberi jog, kiváltképpen a környezethez való jog}

Az egész folyóiratszám a kereszténység és az emberi jogok témájának lett szentelve, így aligha szükséges, hogy magam is bemutassam az erre vonatkozó egyházi megnyilatkozások történetét, amelyek nagyban-egészben egybeestek a környezeti problémák iránti érdeklődés megjelenésével. Arról azonban nem feledkezhetünk meg, hogy a társadalmi tanítás alapja mindenképpen a Rerum novarum, amelynek kiemelkedő üzenete a közjóról való gondoskodás: „26. [...] Az állam irányítóinak mindenekelőtt általában és egységesen a törvények és intézmények olyan teljes rendszerén kell munkálkodniuk, amelynek eredményeképpen már magából az állam rendszeréből és irányításából mintegy automatikusan adódik a közösség és az egyének jóléte." Majd még világosabban: „az államnak törvényes kötelessége a közjó előmozdítása”, illetve „29 [...] az államnak minden ember jogát, legyen az bárki, szentül meg kell védenie”. Nem más ez, mint az emberi jogok egyértelmű elismerése több mint fél évszázaddal azelőtt, hogy a nemzetközi közösség hasonló felismerésre jutva, megfogalmazta volna az Emberi jogok egyetemes nyilatkozatát. Ugyanezen enciklikában a mai értelemben vett teremtésvédelem ennyire markánsan nem fogalmazódott meg.

Az ok pedig nyilvánvaló, és ez az ember központi szerepea Teremtésben: „6. [...] Az ember ugyanis régebbi, mint az állam, ezért természeténél fogva előbb kellett legyen joga életének fenntartására, mint hogy bármely államalakulat létrejött volna." Mindennek forrása pedig az, hogy: „7. [...] Isten a földet az egész emberi nemnek adta, hogy használja és gyümölcseit élvezze." Az ember ilyenképpen központi szerepe tehát megköveteli a jogokról való gondoskodást is, hiszen az ember jogai korábbiak, a kezdetekre, a teremtésre tehetők.

E téren többek mellett kiemelkedő alapnak tekintem a Pacem in terrist: „28. Az eddig említett jogokkal, amelyek a természetből erednek és minden embert megilletnek, járnak az ugyanolyan kötelezettségek; e törvények és kötelezettségek vagy a természetjogból származnak, vagy az parancsolja őket, és onnét veszik eredetüket, fennmaradásukat és kötelező erejüket. [...] 75. Ezekből a megtárgyalt kérdésekből világosan kitünik, hogy a mi korunkban az államok jogszolgáltatási rendje elsősorban azt követeli, hogy a fóbb jogokat, amelyek az embereknek sajátjai, rövid és érthetö szavakba sürítve megfogalmazzák és az állam egyetemes alkotmányába bevegyék." 
A fejlődés valós értékeire és tartalmára nézve is figyelmet érdemel a Sollicitudo rei socialis enciklika: „33. [...] A valódi fejlődés és az emberi jogok közötti belső kapcsolat a fejlődés erkölcsi összefüggéseit is előtérbe állítja: az ember valódi felemelkedése, amely megfelel természetes és történelmi hivatásának, nem szorítkozhat csupán a javak és szolgáltatások bőségére, a technikai felkészültségre, amelyet infrastruktúrának nevezünk." A következő pont lesz itt, amit már az előzőekben említettem, a teremtés (teremtmények) tisztelete.

Ígéretemhez híven nem bonyolódunk bele részletesen a Vatikán és az emberi jogok viszonyába, elegendő és egyben a kép teljessége érdekben szükséges is II. János Pál pápa első, Redemptor hominis enciklikájára utalni, annak is egyik alcímére: 17. Az emberi jogok: betü vagy lélek?

„Az Egyesült Nemzetek Szervezetének megalapítása és az Emberi Jogok Nyilatkozata kétségtelenül nemcsak arra irányult, hogy megakadályozza a legutóbbi háború borzalmainak megismétlődését, hanem olyan alapot akart teremteni, amelyhez a rendszereket, programokat és az államok irányítási formáit hozzá lehessen mérni abból az egyetlen alapvető szempontból nézve, ami az ember - a közösségben élö személy - java, amely elemi alkotórésze a közjónak, és elsődleges kritériumul kell szolgálnia minden tervhez, rendszerhez és kormányzáshoz.

Az Egyház mindig azt tanította, hogy a közjóért fáradozni kell, így minden államnak jó állampolgárokat nevelt. Ugyanakkor figyelmeztette a közhatalom viselőit, hogy elsődleges feladatuk a közjóról való gondoskodás, s hogy alapvető jogaik innen származnak. Az előbb vázolt premisszák és az objektív etikai rend követelményei miatt a közhatalom jogait csak az ember természetes és sérthetetlen jogainak figyelembevételével lehet értelmezni. Az a közjó, amelynek a közhatalom képviselői a szolgálatában állnak, csak akkor valósul meg akadálytalanul, ha az állampolgárok biztosak lehetnek jogaik felől."

A közjó tehát egyrészt az, ami összeköti a teremtésvédelem és az emberi jogok kérdését, általában és ezen belül is az az állami szerepvállalás, amely mindkét esetben kiindulási alap. A közjót kell elsősorban az államnak megvalósítania, ennek akármilyen vonatkozásáról is szólunk. A másik alapvető összefüggés pedig az emberi méltóságban lelhető fel, amelynek tartalma bővül, illetve átrendeződik, egyes kérdések már bevettek, mások pedig most vannak alakulóban - a környezet inkább az utóbbi körbe sorolható. E kapcsolat tudatosodása harminc évvel ezelőtt már szükségképpen vezetett el a következtetésig, amelyet ugyancsak II. János Pál pápa fogalmazott meg, elsőként ismét egy békevilágnapi üzenetben (1990), amelynek egyik következtetése teljesen világos: „7. Az élet, és mindenekelőtt az emberi méltóság tisztelete az alapvető vezérlő elve mindenfajta egészséges gazdasági, ipari vagy tudományos fejlődésnek. [...] 9. [...] Manapság egyre erőteljesebben vetődik fel az egészséges környezethez való jog, amely a megújított Emberi jogok egyetemes nyilatkozatának részét kell képezze." 
II. János Pál pápa ezt az üzenetet majdnem egy évtizeddel követően (1999) egy teljes békevilágnapi üzenetet szentelt az emberi jogoknak, ${ }^{33}$ kiindulási pontnak tekintve az emberi méltóságot, folytatva az emberi jogok egyetemességével és oszthatatlanságával, majd kiemelve egyes, újabban egyre jelentősebbé váló emberi jogokat. Ezek között elsőként említi az élethez való jog egyes új összetevőit, amelyek között az erőszak minden fajtája elleni fellépés is helyet kapott, így a „természeti környezet esztelen károsítása" mint erőszakos cselekmény, egybefoglalva az emberi méltósággal (4. pont). A vallásszabadságot természetesen központi kérdésnek tekinti a pápa, majd a részvételi jogokra lép át, amelyek - noha itt kifejezetten a demokratikus jog mivoltuk miatt szerepelnek - a környezetvédelemnek is alapelvi szintű összetevőjét jelentik. A diszkrimináció valamennyi formájának tilalma, az önmegvalósítás joga, a szolidaritás és a béke mellett a 10. pont a környezetért való felelösségre vonatkozik:

„10. Az emberi méltóság elösegitése az egészséges környezethez való joggal összefügg, mert e jog rávilágít az egyén és a társadalom közötti viszony dinamikájára. Nemzetközi, regionális és nemzeti normák fokozatosan jogi formába öntik ezt a jogot. A jogszabályok azonban önmagukban nem elégségesek. [...] A világ jelene és jövője a Teremtés védelmétől függ, az ember és környezete közötti végtelen egymásra utaltság miatt. Az emberi jólétnek a környezetért érzett felelősség központjába helyezése a Teremtés védelmének legbiztosabb útja; ez valójában ösztönzi az egyén felelősségét a természeti erőforrások és azok igazságos használata irányába."

Az első üzenetből idézett utolsó mondat, illetve a külön specifikus üzenet következtetései vagy inkább elvárásai különösen fontossá válnak annak tudatában, hogy a nemrégiben (2018) 70 éves Nyilatkozat, de az idén (2020) szintén 70 éves Emberi jogok európai egyezménye azóta sem tesz közvetlen említést az egészséges környezethez való jogról. Hiába a számos eddigi erőfeszítés, konferencia, munkacsoport és különleges jelentéstevő, ${ }^{34}$ érdemi előrelépés a nemzetközi elismerés terén nem történt, pedig hitelt kellene adni a már hivatkozott Weeramantry-különvéleménynek: ${ }^{35}$ „A környezet védelme szintén alapvető része az emberi jogok jelenleg érvényes doktrínájának, hiszen számos emberi jognak, így például az egészséghez, illetve az élethez való jognak előfeltétele. Aligha szükséges ezt részletesebben kifejteni, mivel a környezetet ért károk az Egyetemes Nyilatkozatban és egyéb emberi jogi okmányokban említett öszszes emberi jogot csorbíthatják, illetve alááshatják."

33 II. János Pál pápa: Az emberi jogok tisztelete az igazi béke titka. Üzenet a béke világnapja alkalmából (1999). Elérhető: www.vatican.va/content/john-paul-ii/en/messages/peace/documents/ hf_jpii_mes_14121998_xxxii-world-day-for-peace.html (A letöltés dátuma: 2020.10.01.)

34 Pl. ENSZ: Special Rapporteur on Human Rights and the Environment. Elérhetö: www.ohchr.org/en/ Issues/environment/SRenvironment/Pages/SRenvironmentIndex.aspx (A letöltés dátuma: 2020. 10. 01.)

Weeramantry i. m. (5. lj.) 
A Centesimus annus egyértelműen fogalmaz: „11. [...] [A]z államnak kötelessége őrködni a közjón, és azon lenni, hogy a társadalmi élet egésze, beleértve a gazdasági szektort is, hozzájáruljon a közjó előmozdításához, tiszteletben tartva minden egyes szektor autonómiáját." És az állam feladata között a környezet kiemelt szerepet kap, lévén ez a kötelezettség mással nem helyettesíthető:

„40. Az állam feladata, hogy gondoskodjon a közösségi javak védelméről, amihez hozzátartozik a természeti és az emberi környezet. Ezek védelmét nem képesek biztosítani kizárólag a piaci mechanizmusok. [...] [A]z egyetemes társadalomnak kell megvédeni a közösségi javakat, amelyek többek között keretet alkotnak, amelyen belül mindenkinek módjában áll, hogy törvényesen valósítsa meg személyes céljait.

Itt a piacnak egy másik korlátját is felfedezhetjük: vannak közösségi és minőségi szükségletek, amelyeket nem lehet a piaci mechanizmusokkal kielégíteni; vannak olyan fontos emberi szükségletek, amelyek nem tartoznak a piac logikájához; vannak olyan javak, amelyek természetükből eredően nem és nem is lehetnek adásvétel tárgyai."

A fenti üzenet a klasszikus állami szerepvállalás terrénumára utal, amikor a védett érdekről való gondoskodás nem vagy nem eléggé hajt gazdasági hasznot, annyira biztosan nem, hogy erre a piac beavatkozás nélkül reagálna. A feladatot viszont el kell látni a társadalom védelme érdekében - esetünkben ez a környezet védelmével egybeesik. A pápai értékelés teljesen korrekt, hiszen minden környezetvédelmi érdekü lépés - legalábbis a kezdetekben - ráfizetésesnek látszik, tehát a gazdaság számára nem profitábilis. Más megoldás kell tehát, mert a feladat viszont nem halasztható.

A harmadik - talán egyben legkevésbé sikeresnek mondható - ENSZ-környezetvédelmi csúcstalálkozót és konferenciát 2002-ben Johannesburgban rendezték meg. A Vatikán is megszólalt, ${ }^{36}$ nem feledkezve meg a jog, illetve a környezethez való jog említéséről sem. E tekintetben a tíz évvel korábbi Riói nyilatkozat ${ }^{37}$ adja a megfelelő kiindulási alapot, annak is első elve („A fenntartható fejlődés érdekeinek középpontjában az emberek állnak. Ők jogosultak - a természettel összhangban - egészséges és termékeny életre"), kiemelve ezzel az ember központi szerepét. Ehhez, ismerve az eddigi egyházi megnyilatkozásokat, mindenképpen az emberi méltóság kiterjesztett értelmezése kapcsolható legjobban. „Az emberi méltóság előmozdítása a fejlődéshez és az egészséges környezethez való joggal kapcsolódik össze, hiszen ezen jogok mutatnak rá az egyén és a társadalom közötti kapcsolatok dinamizmusára,

36 Intervention by the Holy See at the World Summit on Sustainable Development (Johannesburg, South Africa, 26 August - 4 September), Address of H.E. Msgr. Renato R. Martino. Elérhető: www. vatican.va/roman_curia/secretariat_state/documents/rc_seg-st_doc_20020902_martino-johannesburg_en.html (A letöltés dátuma: 2020.10. 01.)

37 ENSZ: Riói Nyilatkozat a Környezetről és a Fejlődésről. Elérhető: www.nyf.hu/others/html/kornyezettud/megujulo/Fenntarthato\%20fejlodes/A\%20Rioi\%20Nyilatkozat.htm (A letöltés dátuma: 2020. 10. 01.) 
ezek ösztönzik az ember saját maga, a mások, a teremtés és végső soron az Isten iránti felelösségét."

Az Egyház társadalmi tanításának kompendiuma ${ }^{38}$ sem tekinthet el az emberi jogok kiemelt tárgyalásától. Erre a Harmadik fejezet IV. részében kerül sor, amelynek kiindulási pontja szerint: „152. Az emberi jogok meghatározásának és meghirdetésének folyamata az egyik legfontosabb azon erőfeszítések között, amelyeknek az a célja, hogy hatékony felelet szülessen az emberi méltóság nélkülözhetetlen követelményeire." Noha általában az Egyház és az emberi jogok kérdésének tárgyalása nem e cikk feladata, még egy gondolatot mindenképpen ki kell emelni, mielőtt ennek környezetvédelmi vonatkozásaira térnék át, és ez az emberi jogok egységes szemléletének fontossága: „154. Nem csupán az egyes emberi jogokat kell védelmezni külön-külön, hanem azok együttesét is; részleges védelmezésük ugyanis a jogok hiányos elismerése lenne." És ehhez tartozó, a környezeti témákhoz való általános hozzáállást ugyancsak erőteljesen meghatározó gondolat: „156. Amint a Tanítóhivatal megnyilatkozásai is erőteljesen hangsúlyozzák, az emberi jogok kérdéséhez elválaszthatatlanul kapcsolódik a kötelességek témája."

A Kompendium környezetvédelemmel foglalkozó fejezetében elsősorban kiemelt figyelmet érdemel általában a jogi szabályozás - természetesen messze nem kizárólagos - fontosságának hangsúlyozása: „468. A környezetért való felelősségnek megfelelő módon kell jogilag kifejeződnie." Ezzel vezeti fel a Kompendium az emberi jogi következtetéseket, és vázolja fel azt a folyamatot, amelyet sajnos még most sem fejeztünk be:

„»A biztonságos és egészséges természeti környezethez való jog « tartalma olyan lépésről lépésre haladó munkálkodásnak lesz az eredménye, amelyet a közvélemény elvárása mozgat, amely a teremtett javaknak a közjó követelményei szerinti felhasználására irányul és annak szabályozására, hogy mindaz, ami a környezetet szennyezi, büntetéssel járjon. Egyedül a jogi normák azonban nem elegendők. Ezek mellett nagy felelősségtudatra, a mentalitás és az életstílus valódi megváltoztatásának beérésére van szükség."

A pápai megnyilatkozások - a Kompendium előtt, és nyugodtan állíthatjuk, hogy annak elfogadását követően is - tehát markánsan érvényesülnek. Említést érdemel a megfogalmazás maga, annak határozottsága, mert ebben a formában ennyire világosan az enciklikák és üzenetek nem minden esetben foglalnak állást. A biztonságos környezet a békével való nyilvánvaló összefüggésre utal, az egészséges viszont általában elfogadott minőség.

A Caritas in veritate környezetvédelemre és jövő generációk védelmére utaló fentebb említett hivatkozásai, illetve a Kompendium figyelmeztetése kapcsán nem meglepő XVI. Benedek pápa ugyanezen enciklikában megjelenő, számomra legfontosabb üzenete: „43. [...] A jogok eltúlzása a kötelességek mellözésébe torkollik. [...] Így a kö-

38 Az Igazságosság és Béke Pápai Tanácsa i. m. (25. lj.) 
telességek a jogokat erősítik és mintegy a jó szolgálatában vállalt feladatként védelmet, támogatást kínálnak amazoknak." Az üzenet eddig még itt nem idézett folytatása szerint: „48. [...] A teljes körű emberi fejlődést szolgáló programoknak ezért [...] nyitottnak kell lenniük arra a nemzedékek közötti szolidaritásra és igazságosságra, amelynek a nevében sokféle - ökológiai, jogi, gazdasági, politikai és kulturális - területen számadással tartoznak." Arról aligha kell értekeznünk, hogy valamilyen jog csak akkor nyer értelmet, ha ahhoz mások kötelezettségei kapcsolódnak, és ezek között éppen a nemzetközi közösség és az állam kötelezettségei lesznek kiemelkedően fontosak. Ez persze távolról sem azt jelenti, hogy az állam mellett másoknak nincsenek kötelezettségeik, hiszen az enciklika előbbi idézeteiben világosan rajzolódik ki a képlet - amint mi bánunk a környezettel, az a jele annak is, miként bánunk másokkal -, hogy mindenki kötelességéről van szó. A környezeti értékek terén ezért elsőként a kötelezettségeket, követelményeket kell kiépíteni, nem lévén időnk arra várni, hogy majd azok maguktól is megjelennek.

Ugyancsak hangsúlyossá válik a kötelezetti oldal a Laudato si' enciklikában: „67. Nem mi vagyunk Isten. A föld létezett már előttünk, és mi ajándékba kaptuk. [...] Ez egymás iránti felelős viszonyt jelent az ember és a természet között. Minden közösség kiveheti a föld javaiból, amire szüksége van az életben maradáshoz, de kötelessége meg is védeni és biztosítani termékenysége folyamatosságát a jövőbeli nemzedékek számára.” A kiindulás most is a közjó: „159. A közjó fogalma magában foglalja a jövő nemzedékeit is", amiből és az annak védelme iránti alapvető követelményekből az emberi jogokra is következtethetünk: „157. A közjó feltételezi az emberi személy, mint olyan tiszteletben tartását, a maga elidegenithetetlen alapjogaival, amelyek teljes kibontakozásához szükségesek. [...] Az egész társadalom - és benne különösen az állam - köteles védelmezni és előmozdítani a közjót." Van tehát közvetlen utalás az alapjogokra általában és azok széles körü kapcsolatrendszerére is. Mindehhez szorosan köthető az emberi élet teljességének és a fejlődés kizárólagos gazdasági szempontoktól elvonatkoztató, az életminőségre koncentráló értelmezésének fontossága is (IV. Politika és gazdaság - párbeszédben az emberi teljesség érdekében).

Végezetül még két újabb vatikáni megnyilatkozásra hívnám fel a figyelmet, mindkettő az Emberi jogok egyetemes nyilatkozata 70. évfordulójához köthető. Időrendben az első Ferenc pápa újévi köszöntője a Szentszékhez akkreditált diplomatákhoz. ${ }^{39}$ Az évforduló kapcsán elsősorban a Szentszék emberi jogokkal kapcsolatos általános véleményeként leszögezi a pápa, hogy az ember központi szerepének valóságához, Isten képére és hasonlatosságára formált mivoltához elengedhetetlenek az emberi jogok. Ezt követően felhívja a figyelmet az emberi jogok katalógusa változására, "új jogok” megjelenésére, így az egészség megőrzéséhez való jogra vagy az élethez való jog és a béke kapcsolatára. Majd a beszéd eljut ahhoz, hogy különösen indokolt, hogy

39 Address of His Holiness Pope Francis to the Members of the Diplomatic Corps Accredited to the Holy See for the Traditional Exchange of New Year Greetings. Regia Hall, Monday, 8 January 2018. Elérhető: www.vatican.va/content/francesco/en/speeches/2018/january/documents/papa-francesco_20180108_corpo-diplomatico.html (A letöltés dátuma: 2020.10.01.) 
törődjünk földünkkel, aminek része a természettel való kölcsönhatásból eredő kötelezettségünk. Az éghajlatváltozás ürügyén pedig a jövő nemzedékek jogai felé irányítja a gondolatokat.

A másik, ugyancsak évfordulós megnyilatkozás a Vatikán államokkal való kapcsolatért felelős államtitkárától származik, ${ }^{40}$ és ebben a béke integráns részének tekinti a legszegényebb nemzetek támogatása mellett a környezetért való felelösséget, mint ami „az emberi jogok előmozdításának és védelmének nélkülözhetetlen része”. "Minden összefügg" - idézik Ferenc pápa Laudato si' enciklikáját, így a környezetért való felelősség is összefügg a jogok gyakorlásával. Ugyanott jelenik meg az integráns ökológia mint az ezen összefüggés nyilvánvaló következménye, ami ugyan eltér valamelyest az emberi jogok hagyományos, szűk értelemben vett rendszerétől, de az emberi jogok összességének támogatásához szorosan hozzátartozik.

A két beszéd nem teljesen azonos koncepciót képvisel, az első kicsit erőteljesebben utal arra, hogy az emberi jogok katalógusa bővítésre vár, és ebben a környezettel kapcsolatos jogok is szükségképpen helyet kapnak, míg a második inkább a környezetvédelem eszközszerepét emeli ki. Figyelemre méltó, hogy ezt a párhuzamos megközelítést alkalmazza az Alaptörvény is, amikor XX. cikkében a testi és lelki egészség megvalósításának eszközeként tekint a környezetvédelemre, míg a XXI. cikk ennél átfogóbb, az egészséges környezethez való jog világos megfogalmazása.

Nem feledkezhetünk meg arról sem, hogy - mint minden esetben, amikor a környezethez való jogról értekezünk - felmerülhetnek olyan részterületek, amelyek önálló szerepre törnek, méghozzá teljes joggal. ${ }^{41}$ Ezek között is kiemelt helyet kap a vízhez való jog, mert ennek közvetlen kapcsolata az emberi élethez vitán felül áll. Ha másról, így a biodiverzitásról beszélünk, ott sokak számára annak szerepe az ember életében kevésbé nyilvánvaló, de a víz létszükséglet mivolta nem lehet kérdéses. Így nem csoda - különösen a hátrányos helyzetü, fejlődő országokbeli vagy éppen anyagi szempontból hátrányos helyzetủ embereket, embercsoportokat kiemelten támogató egyházi szemlélet ismeretében -, ha a megfelelő minőségű vízhez való hozzáférés is központi helyet kap ebben a gondolkodásban.

A vízhez való jogra mindössze két példát említünk a számos hasonlóból anélkül, hogy tárgyalnánk a részleteket. Az egyik az Igazság és Béke Pápai Tanácsától származó megnyilvánulás a 2003-as Víz Világfórumon. ${ }^{42}$ Külön figyelmet érdemel ebből az az utalás is, amely szerint „[a] víznek valóban kiemelkedő jelentősége van a nagy

40 Intervention of the Secretary for Relations with States at the Council of Europe for the Celebration of the 70th Anniversary of the Universal Declaration of the Rights of Man, 10.09.2018. Elérhetö: https://press.vatican.va/content/salastampa/en/bollettino/pubblico/2018/09/11/180911d.html (A letöltés dátuma: 2020.10. 01.)

41 Számos helyen olvashatunk erről, pl. Linda Hajjar Leib: Human Rights and the Environment: Philosophical, Theoretical and Legal Perspectives. Hága, Martinus Nijhoff, 2011.

42 Note Prepared by the Pontifical Council for Justice and Peace: A Contribution of the Delegation of the Holy See on the Occasion of the Third World Water Forum (Kyoto, 16-23 March 2003). Elérhető: www.vatican.va/roman_curia/pontifical_councils/justpeace/documents/rc_pc_justpeace_doc_20030322_kyoto-water_en.html (A letöltés dátuma: 2020.10. 01.) 
világvallások számára" (I. pont). A vízre vonatkozó etikai megfontolások kapcsán pedig nem lehet kétséges, hogy „[a] teremtés adományai egyetemes rendeltetésének elve alátámasztja, hogy az emberek és országok, beleértve a jövő nemzedékeket is, hozzáférést kell kapjanak mindazon javakhoz, amelyek fejlődésükhöz szükségesek. A víz az emberiség közjava" (II. pont). Majd később már egyértelműbben kimondva: „Az elegendő és biztonságos ivóvíz minden más emberi jog érvényesülésének előfeltétele" (VI. pont). És levezeti azt a gondolatot, hogy ennek igazsága annyira természetesnek tűnik általában mindenki számára, hogy mintegy elfeledkezünk ennek jogként történő megjelenítéséről - holott nyilvánvalóan sok millió ember életében a vízhez való hozzáférés egyáltalában nem természetes. „Egyre erősebb az a mozgalom, ami azt szorgalmazza, hogy formálisan is fogadjuk el a vízhez való emberi jogot." Ez már az emberi méltóság miatt is nélkülözhetetlen, hiszen „[a] jog az élet nélkülözhetetlen szükséglete. [...] Ezért a vízhez való jog elidegenithetetlen jog."

2007-ben a víz világnapján a vízhez való jog kapcsán XVI. Benedek pápa is megszólalt. ${ }^{43}$ Az üzenet szerint "[a] vízhez való hozzáférés minden ember elidegenithetetlen joga, mert előfeltétele a további emberi jogok többségének megvalósulásához, mint az élet, az élelmiszer és az egészség". Ezzel és a továbbiakkal valójában megismétli az előzőleg mondottakat, világossá téve a Vatikán álláspontjának folytonosságát.

\section{5. Összegzés és következtetések}

Az ember központi szerepének - és így nem vitásan jogainak - elismerése jelenti a keresztény tanítások gyökereit. Nem csoda, hogy az emberi jogok kiemelkedő szerepének hangsúlyozása sokkal előbb jelenik meg az egyházi megnyilatkozásokban, mint a nemzetközi politikában. A környezet és természet védelme - eredendően: a Teremtés védelme - nem különben az alapoktól része a kereszténység tanításának, számos szálon, a Teremtés könyvétől kezdve annak integráns eleme. A Katolikus Egyház mai fogalmaival ez az Egyház társadalmi tanításának egyik összetevője. Noha a fentiekben szinte teljes egészében a Katolikus Egyház tanítására hagyatkoztunk, mint amelyet a legteljesebben, egységes rendszerben és egyértelműen közvetítenek a pápák és a Vatikán, valamint ennek következtében a legjobban is megismerhető, bizton állíthatjuk, hogy egészében minden keresztény vallás következtetései ennek alapjaiban megfelelnek. Az ember tehát társörökös a Teremtésben, de egyre jobban megfeledkezett az ezzel járó kötelezettségekről, és elnyomóként („garázda birtokosként”), nem pedig gondos gazdaként viselkedik az őt körülvevő környezettel, pusztítja és rombolja, károsítja és használat közben fel is éli. Ugyanakkor nem lehet kétséges, hogy jogokra is alappal csak az hivatkozhat, aki maga is tiszteli mások jogait, tehát megéli kötelezettségeit.

43 Message of the Holy Father Benedict XVI, Signed by Cardinal Tarcisio Bertone to the Director General of FAO on the Occasion of the Celebration of World Water Day 2007. Elérhető: www.vatican.va/roman_curia/secretariat_state/card-bertone/2007/documents/rc_seg-st_20070322_giornata-acqua_en.html (A letöltés dátuma: 2020. 10. 01.) 
A kereszténység ilyetén általánosnak mondható szemlélete természetjogi alapként megjelenik akár a magyar Alkotmánybíróság hivatkozási listáján is, hiszen annak szükségét, hogy a környezethez való jog értelmezése általános etikai alapokon kell nyugodjon, senki sem vitathatja el. Legjobban ezt a vízügyi törvény módosításával kapcsolatos (ismertebben: „kútfúrásos”) határozata példázza, ${ }^{44}$ ahol ezek az erkölcsi megfontolások közvetlen érvként is szolgálnak. „[36] A biológiai sokféleség megőrzésének természetjogi alapjaira hívta fel a figyelmet Ferenc pápa »Laudato si’« kezdetű enciklikájában: »Minden évben több ezer növény- és állatfaj tűnik el, amelyeket többé már nem ismerhetünk meg, gyermekeink már nem láthatják őket, örökre elvesztek. Túlnyomó többségük emberi beavatkozáshoz kapcsolódó okok miatt hal ki.« Az enciklika kategorikusan fogalmaz: »Ehhez nincs jogunk.« A földi élet megóvása utódaink részére a természetjogi kötelezettségen túl »az igazságosság egyik alapkérdéséről« is szól, és a legszorosabb összefüggésben áll az emberi méltóság kérdésével és magának az emberi életnek a céljával is (Ferenc pápa: Laudato si' enciklika). Bartholomaiosz pátriárka egyenesen »a természet ellen elkövetett bủntettről «beszél azon emberi cselekmények kapcsán, amelyek lerombolják »Isten teremtett világának biológiai sokszínűségét« (Bartholomaiosz ökomenikus pátriárka ökológiai víziója és kezdeményezései)."

A Katolikus Egyház - és alapjaiban a kereszténység - pedig a környezeti válságjelenségek sokasodásával párhuzamosan megpróbálja visszavezetni az emberiséget a helyes útra, amely a jelenlegi életforma, gazdasági rend, fogyasztói társadalom alapvető megváltoztatása, elsősorban etikai megújulása kell legyen. Nem vitás, hogy sem a gazdaság, sem a technika nem elegendő a környezeti válság megoldására. Ezt az etikai megújulást mondhatjuk ökológiai megújulásnak, illetve ökológiai megtérésnek is.

Ami kétségkívül az emberi jogokkal való összefüggés alapja, az nem más, mint a közjó és az emberi méltóság. A közjó - ami minden embernek és társadalomnak jó és nem csak keveseknek - a Teremtés értékei nélkül, a teremtett javak és élőlények tisztelete és kímélete nélkül aligha érhető el, hiszen a közjó messze nem anyagi szemléletủ (gondoljunk arra, milyen különbséget rejthet, vajon jólétet vagy jóllétet szeretnénk elérni), hanem annál sokkal teljesebb értékrendet feltételez. Az emberi méltóság úgyszintén már a kezdetektől magában foglalja a környezet és természet tiszteletét és védelmét, annál is inkább, mert az emberi méltóság tartalmi összetevőinek felismerése és azok súlya, belső aránya az idők során változik, de az soha nem volt kétséges, hogy mindez az emberi élet teljességéhez szükséges feltételek összességét fogja át.

Az emberi méltóság teljessége tükröződik az emberi jogokban is, márpedig a környezeti értékek védelme nélkül az emberi jogok nem érvényesíthetők - gondoljunk csak a vízhez való jog kapcsán a víz mint alapvető életfeltétel kérdésére -, nem valósíthatók meg. A környezethez való jog érvényesülése a többi emberi jog alapja. Innen pedig már nem kell nagyot lépnünk ahhoz, hogy - a leggyakrabban az „egészséges" jelzős szerkezettel megjelenő - emberi jogokat ebbe az irányba is bővítsük. 
Arról sem feledkezhetünk meg, hogy e téren kiváltképpen nagy jelentősége van a jogok kötelezetti oldala kiemelésének, hiszen - amint az Alaptörvény P) cikke, majd az Alkotmánybíróság elmúlt évekbeli gyakorlata ezt részletesen kifejti - a jelen és a jövő nemzedékek megfelelő életminőségéről való gondoskodás az állam és mindenki kötelezettsége, de ezen belül az államnak - és természetesen elsősorban az államok közösségét jelentő nemzetközi közösségnek - ebben kiemelt felelőssége jelenik meg. Ahogy XVI. Benedek fogalmaz: „Az embert kell védelmeznie mindenekelőtt, saját önpusztítása ellenében." ${ }^{45}$

A kereszténység, így a Katolikus Egyház számára a környezethez való jog emberi jogként történő elismerése a teremtésvédelemből, valamint ezzel összefüggésben az ember központi szerepéből kiindulva a közjó és az emberi méltóság részeként, illetve mindkettőnek egyben nélkülözhetetlen feltételeként nyer különös fontosságot, emlékeztetve egyszersmind az embert/emberiséget saját felelősségére e téren. Ismét a Caritas in veritate gondolatára hivatkozom zárásként: „51. Az a viselkedési minta, amely alapján az ember a környezettel bánik, befolyással van arra a viselkedési módra is, ahogyan önmagával bánik, és viszont."

\section{Irodalomjegyzék}

II. Vatikáni Zsinat: Gaudium et spes (1965). Elérhető: https://regi.katolikus.hu/konyvtar.php?h=16 (A letöltés dátuma: 2020. 10. 01.)

Address of His Holiness Pope Francis to the Members of the Diplomatic Corps Accredited to the Holy See for the Traditional Exchange of New Year Greetings. Regia Hall, Monday, 8 January 2018. Elérhető: www.vatican.va/content/francesco/en/speeches/2018/january/documents/papa-francesco_20180108_corpo-diplomatico.html (A letöltés dátuma: 2020. 10. 01.)

A Magyar Katolikus Püspöki Konferencia: Felelősségünk a teremtett világért (2008). Elérhető: www. teremtesvedelem.hu/content/korlevel/felelossegunk-teremtett-vilagert (A letöltés dátuma: 2020. 10. 01.)

Az Igazságosság és Béke Pápai Tanácsa: Az Egyház társadalmi tanitásának kompendiuma (2004). Elérhető: www.vatican.va/roman_curia/pontifical_councils/justpeace/documents/rc_pc_justpeace_doc_20060526_compendio-dott-soc_hu.html (A letöltés dátuma: 2020.10. 01.)

Benedek, XVI., pápa: Caritas in veritate (2009). Elérhető: https://regi.katolikus.hu/konyvtar. $\mathrm{php}$ ?h=397 (A letöltés dátuma: 2020. 10. 01.)

Benedek, XVI., pápa: Ha békére törekszel, védd a teremtett világot (2010). Elérhető: https://regi.katolikus.hu/konyvtar.php?h=229 (A letöltés dátuma: 2020. 10. 01.)

ENSZ: Riói Nyilatkozat a Környezetről és a Fejlődésről. Elérhető: www.nyf.hu/others/html/kornyezettud/megujulo/Fenntarthato\%20fejlodes/A\%20Rioi\%20Nyilatkozat.htm (A letöltés dátuma: 2020. 10. 01.)

ENSZ: Special Rapporteur on Human Rights and the Environment. Elérhető: www.ohchr.org/en/Issues/environment/SRenvironment/Pages/SRenvironmentIndex.aspx (A letöltés dátuma: 2020. 10. 01.)

ENSZ: Világunk átalakitása: a fenntartható fejlődés 2030-ig megvalósitandó programja.

45 Caritas in veritate i. m. (27. 1j.) 51. pont. 
ENSZ Környezet és Fejlődés Konferencia: Riói Nyilatkozat a Környezetről és a Fejlődésről (1992). Fizikai Szemle, 43. (1993), 4. 123-124.

European Christian Environmental Network: The Churches' Contribution to a Sustainable Europe (2005). Elérhető: www.ecen.org/index.php/articles/churches-contribution-sustainable-europe (A letöltés dátuma: 2020. 10. 01.)

Ferenc pápa: A béke mint a remény útja. Elérhető: www.katolikus.hu/cikk/ferenc-papa-uzenete-a -beke-53-vilagnapjara-a-beke-mint-a-remeny-utjaparbeszed-megbekeles-es-okologiai-megter es (A letöltés dátuma: 2020. 10. 01.)

Ferenc pápa: Laudato si' (2015). Elérhető: https://regi.katolikus.hu/konyvtar/ferenc_papa_laudato_si_enciklika.pdf (A letöltés dátuma: 2020.10. 01.)

Hajjar Leib, Linda: Human Rights and the Environment: Philosophical, Theoretical and Legal Perspectives. Hága, Martinus Nijhoff, 2011. DOI: https://doi.org/10.1163/ej.9789004188648.i-182

Intervention by the Holy See at the World Summit on Sustainable Development (Johannesburg, South Africa, 26 August - 4 September), Address of H.E. Msgr. Renato R. Martino. Elérhető: www.vatican.va/roman_curia/secretariat_state/documents/rc_seg-st_doc_20020902_martinojohannesburg_en.html (A letöltés dátuma: 2020.10. 01.)

Intervention of the Secretary for Relations with States at the Council of Europe for the Celebration of the 70th Anniversary of the Universal Declaration of the Rights of Man, 10.09.2018. Elérhetö: https://press.vatican.va/content/salastampa/en/bollettino/pubblico/2018/09/11/180911d.html (A letöltés dátuma: 2020. 10. 01.)

János, XXIII., pápa: Pacem in terris (1963). Elérhető: www.vatican.va/content/john-xxiii/hu/encyclicals/documents/hf_j-xxiii_enc_11041963_pacem.html (A letöltés dátuma: 2020.10.01.)

János Pál, II., pápa: Redemptor hominis (1979). Elérhető: https://regi.katolikus.hu/konyvtar. php?h=206 (A letöltés dátuma: 2020. 10. 01.)

János Pál, II., pápa: Sollicitudo rei socialis (1987). Elérhető: https://regi.katolikus.hu/konyvtar. $\mathrm{php}$ ?h=93 (A letöltés dátuma: 2020. 10. 01.)

János Pál, II., pápa: Békesség a teremtő Istennel. Békesség az egész teremtett világgal (1990). Elérhető: www.teremtesvedelem.hu/content/cikk/az-okologiai-valsag-kozos-felelossegunk (A letöltés dátuma: 2020. 10. 01.)

János Pál, II., pápa: Centesimus annus (1991). Elérhető: https://regi.katolikus.hu/konyvtar.php?h=86 (A letöltés dátuma: 2020. 10. 01.)

János Pál, II., pápa: Evangelium vitae (1995). Elérhető: https://regi.katolikus.hu/konyvtar.php?h=78 (A letöltés dátuma: 2020. 10. 01.)

János Pál, II., pápa: Az emberi jogok tisztelete az igazi béke titka (1999). Elérhető: www.vatican. va/content/john-paul-ii/en/messages/peace/documents/hf_jp-ii_mes_14121998_xxxii-worldday-for-peace.html (A letöltés dátuma: 2020.10. 01.)

János Pál, II., pápa: Ne engedd, hogy legyözzön a rossz, hanem te gyözd le a rosszat jóval. A pápa üzenete a béke világnapjára (2005). Elérhető: https://regi.katolikus.hu/konyvtar.php?h=24 (A letöltés dátuma: 2020. 10.01.)

János Pál, II., pápa - Bartholomaiosz, I., ökumenikus pátriárka: Velencei Nyilatkozat (2002). Elérhető: http://www.teremtesvedelem.hu/content/cikk/velencei-nyilatkozat (A letöltés dátuma: 2020. 10. 01.)

Lacey, Josie: Environmental Ethics in Judaism (2006). Elérhető: www.ijs.org.au/environmental-ethics-in-judaism (A letöltés dátuma: 2020. 10. 01.)

Leó, XIII., pápa: Rerum novarum. Róma, 1891. 
Magyar Katolikus Püspöki Konferencia: Felelösségünk a teremtett világért (2008). Elérhető: www.teremtesvedelem.hu/content/korlevel/felelossegunk-teremtett-vilagert (A letöltés dátuma: 2020. 10. 01.)

Message of the Holy Father Benedict XVI, Signed by Cardinal Tarcisio Bertone to the Director General of FAO on the Occasion of the Celebration of World Water Day 2007. Elérhetö: www. vatican.va/roman_curia/secretariat_state/card-bertone/2007/documents/rc_seg-st_20070322_ giornata-acqua_en.html (A letöltés dátuma: 2020.10. 01.)

Note Prepared by the Pontifical Council for Justice and Peace: A Contribution of the Delegation of the Holy See on the Occasion of the Third World Water Forum (Kyoto, 16-23 March 2003). Elérhető: www.vatican.va/roman_curia/pontifical_councils/justpeace/documents/rc_pc_justpeace_doc_20030322_kyoto-water_en.html (A letöltés dátuma: 2020.10.01.)

Pál, VI., pápa: Populorum progressio (1967). Elérhető: https://regi.katolikus.hu/konyvtar.php?h=462 (A letöltés dátuma: 2020. 10. 01.)

Pius, XI., pápa: Quadragesimo anno (1931). Elérhető: http://tarsadalomformalas.kife.hu/xi-pius-papa-quadragesimo-anno (A letöltés dátuma: 2020. 10. 01.)

Shelton, Dinah: Nature in the Bible. GWU Law School Public Law Research Paper, 371. (2007). Elérhető: https://ssrn.com/abstract=1028357 (A letöltés dátuma: 2020. 10. 01.) 